\title{
Baseline physicochemical investigations on waters from three blue holes, San Salvador Island, Bahamas
}

\author{
Jacqueline M. SAMPSON ${ }^{* *}$ \& Ken GUILBEAULT ${ }^{2}$ \\ ${ }^{1}$ Karst Research Group, Department of Geology, University of South Florida, 4202 E. Fowler Ave., SCA 528, Tampa FL 33620, USA \\ ${ }^{2}$ SCS Engineers, 4041 Park Oaks Blvd., Suite 100, Tampa FL 33610, USA
}

Received: May 2012; accepted January 2013

Available online 4 February 2013

DOI: http://dx.doi.org/10.5038/1937-8602.58.1.2

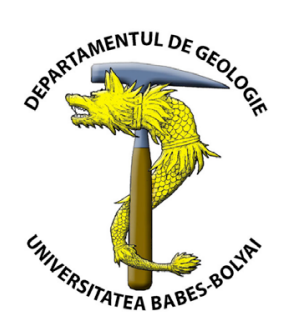

\begin{abstract}
Physicochemical parameters have been studied in the water column of Inkwell, Church, and Watling's Blue Holes (San Salvador Island, Bahamas). Water samples were collected from multiple depths at the three blue holes to identify and characterize changes of physical and chemical parameters. The values were compared to the average ocean concentrations in order to assess how connectivity to the ocean, evaporation, freshwater input, and bacterial activity influence water rock interactions. The salinity concentrations vary between the surface and $\sim-4$ $\mathrm{m}$ in each blue hole before stabilizing to rather similar values $(\sim 19.6 \%)$. Mixing processes in the water column at Inkwell and Church blue holes are inferred from changes in the concentration of chloride. The degree of variation is a mixed signal resulting from changes of the precipitation/evaporation balance and tidal driven water-rock interaction. Inkwell is strongly influenced by tidal pumping, which causes ample value fluctuations, most notably salinity (1.01 to $21.8 \%$ ), chloride $\left(\mathrm{Cl}^{-}\right)$from 300 to $9591.8 \mathrm{mg} / \mathrm{L}$, and total hardness $(9$ to $293 \mathrm{mg} / \mathrm{L}$ ) within the mixing zone. This location is the only site that may have a true halocline. Watlings's geochemical parameters have the smallest range (i.e., salinity $30.19-34.30 \%$ ) due to a lack of mixing that suggests that this site has a direct conduit connection to the ocean. The furthest inland blue hole (Church) lacks significant geochemical fluctuations with the exception of $\mathrm{Cl}^{-}$, which changes from $19600 \mathrm{mg} / \mathrm{L}$ to $1800 \mathrm{mg} / \mathrm{L}$ between the depths of 1 and $2 \mathrm{~m}$. The abrupt modification of $\mathrm{Cl}^{-}$values between surface and $-2 \mathrm{~m}$ suggests mixing is occurring. The lack of other parameter variations within the water column suggests restricted flow via narrow conduits or more likely matrix flow. Salinity values decrease from the surface $\left(21.47 \%\right.$ ) to $\sim-1 \mathrm{~m}\left(17.78 \%\right.$ ) whereas, sulfate $\left(\mathrm{SO}_{4}{ }^{2-}\right)$ concentration at the same depth reach its maximum value $(4009 \mathrm{mg} / \mathrm{L})$. The high sulfate values throughout the column $(2634$ to $4009 \mathrm{mg} / \mathrm{L})$ are characteristic of seawater $(>2700 \mathrm{mg} / \mathrm{L})$, thus indicating seawater seepage into the blue hole. We assume the elevated salinity values at the surface and $-1 \mathrm{~m}$ are pointing towards evaporative processes.
\end{abstract}

Keywords: blue holes, eogenetic karst, geochemistry, San Salvador, Bahamas

\section{INTRODUCTION}

A prominent karst feature throughout the carbonate islands of the Bahamian Archipelago is the so-called blue hole (Palmer, 1985). Blue holes (synonyms: ocean hole, boiling hole) were recognized and reported in various documents as early as 1843 (Shaw, 1993). They were identified by the striking contrast between the dark blue of their deep waters and the lighter blue of the shallows around them. Later studies showed that blue holes could also occur as polygenetic deep holes in lakes or on land surfaces (inland blue holes). For the purpose of our paper we adhere to definition proposed by Mylroie et al. (1995): "Blue holes are subsurface voids that are developed in carbonate banks and islands; are open to the earth's surface; contain tidally-influenced waters if fresh, marine or mixed chemistry; extend below sea level for a majority of their depth, and may provide access to cave passages". For an in-depth look into blue hole morphology, genesis, functionality, and classification, readers should consult Farr and Palmer (1984), Burkeen and Mylroie (1992), Mylroie (2004), and Schwabe and Herbert (2004).

Prior studies involving blue holes on San Salvador Island have focused on identifying the geochemical parameters of salinity, $\mathrm{pH}$, electric conductivity (EC), dissolved oxygen (DO), and $\mathrm{Ca} 2+\mathrm{Mg} 2+$ ratios to characterize the water chemistry in an attempt to better understand the hydrology of the island (Davis and Johnson, 1989; Vermette and Hudson, 2001; Martin et al., 2012). The focus of the present study is to expand the number of geochemical parameters investigated, providing a baseline physicochemical study of the water column in three blue holes from San Salvador Island, Bahamas. Increasing the amount of monitored data should provide new insight into the geochemical changes that occur due to connectivity to the ocean, evaporation, freshwater input, water-rock interaction, and bacterial activity. In turn, this information may aid in understanding the mechanisms that govern the formation and dissolution of carbonates, processes that influence the hydrology of the island (Moore and Martin, 2006), and consequently its karst and cave development. 


\section{GEOGRAPHIC, CLIMATIC, AND GEOLOGIC SETTINGS}

San Salvador is one of the eastern most islands of the Bahamian Archipelago that makes up the Commonwealth of the Bahamas and also the British West Indies (Sealey, 1994). It is located approximately $650 \mathrm{~km}$ southeast of Miami, Florida $\left(24^{\circ} \mathrm{N}\right.$ and $\left.74^{\circ} 30^{\prime} \mathrm{W}\right)$ with an estimated area of 128 $\mathrm{km}^{2}$, spanning $16 \mathrm{~km}$ north-south and $8 \mathrm{~km}$ east-west (Fig. 1). The island of San Salvador represents a carbonate bank, which at least throughout the Tertiary, acted as a tectonicallystable and isostatically-subsiding platform. The entire island consists of transgressive- and regressive-phase Quaternary carbonate deposits (eolianites) that are separated by terra rossa paleosol horizons. The horizons represent prolonged low sealevel stands (Mylroie and Mylroie, 2009), which produced a typical limestone carbonate platform. The topography of the island displays petrified sand dunes, hypersaline lakes and karst morphology (Mylroie and Carew, 1995a).

The climate on the island is subtropical marine dominated by northeast trade winds with an annual temperature range between 22 and $28^{\circ} \mathrm{C}$. Average annual rainfall ranges from 1000 to $1250 \mathrm{~mm} / \mathrm{yr}$ with an estimated potential evaporation rate of 1250 to $1375 \mathrm{~mm} / \mathrm{yr}$., resulting in a negative annual water budget (Sealey, 1994). Between the months of May and October, San Salvador experiences its warm and rainy season followed by a cool, dry period. During the wet season precipitation exceeds evapotranspiration allowing freshwater to percolate through the surface forming a freshwater lens upon the denser marine groundwater (McGee et al., 2010).

Karst features present on the island are referred to as eogenetic karst resulted from different water flow dynamics interacting with diagenetically immature carbonates (Vacher and Mylroie, 2002). Most of the carbonate sediments are still poorly consolidated and stabilization of the depositional mineralogy has not yet been achieved allowing many matrix rocks to retain primary porosity (Martin et al., 2012). The weathering of minerals within the eolianites is an important process that controls the concentration of dissolved ions in groundwater and other water bodies on the island, including the blue holes (Mylroie et al., 1995; Mylroie and Carew, 1995b). Flooded pit caves are inland blue holes, which formed during a sea level low stand resulting from the dissolution of limestone by rapid infiltration of meteoric waters (Vermette and Hudson, 2001).

Similar to the inland blue holes are the cenotes of the Yucatan Peninsula. They are typically classified based on water characteristics. The most common cenotes contain clear, homogeneously well-oxygenated water with a sandy bottom. Development is often the result of passage roof collapse, sometimes limiting water surface exposure (Beddows et al., 2007). Turbulent conduit flow dominates the hydrology of the most common type resulting in horizontal extensions (Beddows et al., 2007). Another common type is the "pit" cenote, typically a bell-shaped vertical shaft, which obtains restricted water flow from narrow conduits and the rock matrix. Horizontal extensions occur infrequently yielding short conduits 10-100s m (Beddows et al., 2007). Some less common cenotes are composed of stratified turbid, stagnant waters accompanied by accumulation of particulate organic carbon at the density interface. The surface water of the second type is alkaline and oversaturated with dissolved oxygen whereas the underlying water is more acidic with elevated concentrations of $\mathrm{H}_{2} \mathrm{~S}$ (Alococer et al., 1998; Martin et al., 2012). Typically, the water in blue holes shows salinity values that range from fresh to saline, with the fresh water floating on the more dense marine water (Vermette and Hudson, 2001).

Blue holes can locally change the characteristics of the mixing zone due to the increase of groundwater circulation (Vacher and Quinn, 1997). In several locations on San Salvador the mixing zone is likely a result of conduits directly or indirectly connecting the blue holes to the ocean. Connectivity can be surmised, in some cases, by the observation of the tidal fluctuations within the blue hole (Davis and Johnson, 1989; Martin et al., 2012). The mixing of freshwater with seawater results in the formation of a density-stratified anchialine lens; if, however, the mixing of the two waters creates a sharp interface with a steep gradient then this stratification is known as halocline (Davis and Johnson, 1989; van Hengstum and Scott, 2011; Martin et al., 2012). Mixing zones within carbonate islands have been recognized as the primary locations for dissolution of carbonates (Back et al., 1986; Mylroie and Carew, 1990; Carew and Mylroie, 1995; Mylroie, 2008). The porosity in the mixing zone can be enhanced by the generation of acids, such as carbonic and sulfuric from bacterial activity in the surrounding rock matrix (Bottrell et al., 1991; Schwabe et al., 2008).

Studies conducted by Schwabe et al. (2008) explain how bacteria contribute to the dissolution potential of carbonate rocks in the vadose and phreatic zones through the production of $\mathrm{CO}_{2}$ and other acids. The largest populations of bacteria reside in the upper portion of the mobile mixing zone. The interface between the upper and lower mixing zones contain accumulations of organics required for bacterial production of high $\mathrm{P}_{\mathrm{CO} 2}$ values ( 3 to 4 times more than in the atmosphere; Palmer, 2007). Sulfate reduction has the potential to suppress or enhance the corrosion of limestone. The reduction of $\mathrm{SO}_{4}^{2-}$ by bacteria follows one of the two pathways:

$$
\begin{aligned}
& 2 \mathrm{CH}_{2} \mathrm{O}+\mathrm{SO}_{4}{ }^{2-}=2 \mathrm{HCO}_{3}^{-}+\mathrm{S}^{0}+\mathrm{H}_{2} \\
& 2 \mathrm{CH}_{2} \mathrm{O}+\mathrm{SO}_{4}{ }^{2-}=2 \mathrm{HCO}_{3}{ }^{-}+\mathrm{H}_{2} \mathrm{~S}
\end{aligned}
$$

where $\mathrm{CH}_{2} \mathrm{O}$ represents a simple sugar molecule as the organic detrital input from the surface (Bottrell et al., 1991). In both equations $\mathrm{HCO}_{3}{ }^{-}$is produced and will tend to suppress dissolution. However, in equation (2) the production of $\mathrm{H}_{2} \mathrm{~S}$ has the potential to generate sulfuric acid, which will further the corrosion of the carbonate bedrock. Such reactions would include the fixing of sulfide (S) with iron $(\mathrm{Fe})$ and the reoxidation of reduced $\mathrm{S}$ species. In both cases the increased acidity would be buffered from the dissolution of calcite, which could preserve the initial pyrite produced from the fixation of $\mathrm{S}$ and locally increase the amount of $\mathrm{Ca}^{2+}$ and $\mathrm{SO}_{4}{ }^{2-}$ due to reoxidation of $\mathrm{S}$, potentially resulting in saturation with respect to gypsum (Bottrell et al., 1991). Having the ability to identify influences within the mixing zones of blue holes by comparing physical and geochemical data would provide a more complete understanding of the water-rock interactions.

\section{CHARACTERISTICS OF THE STUDIED BLUE HOLES}

In December 2008 water samples were collected from three locations: Inkwell Blue Hole, Church Blue Hole, and Watling's Blue Hole. All of the sites are located in the southwestern portion of the island (Fig. 1). Inkwell is the furthest site to the northwest. Relative to Inkwell, Church is located $\sim 200 \mathrm{~m}$ to the southeast and Watling's is $\sim 670 \mathrm{~m}$ due south. 


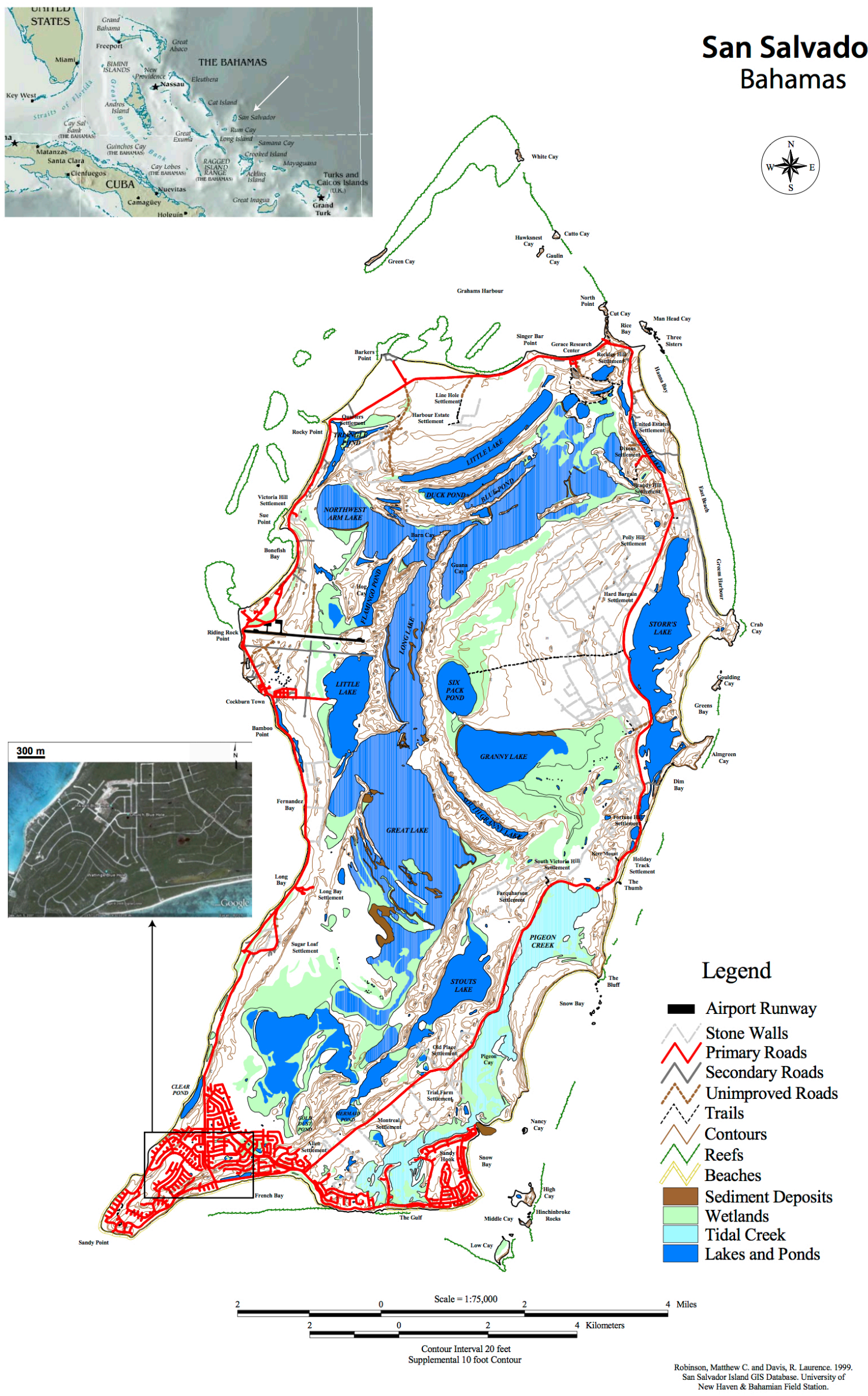

Fig. 1. Location of sampled blue holes on SW part of the San Salvador Island (Bahamian Archipelago). 


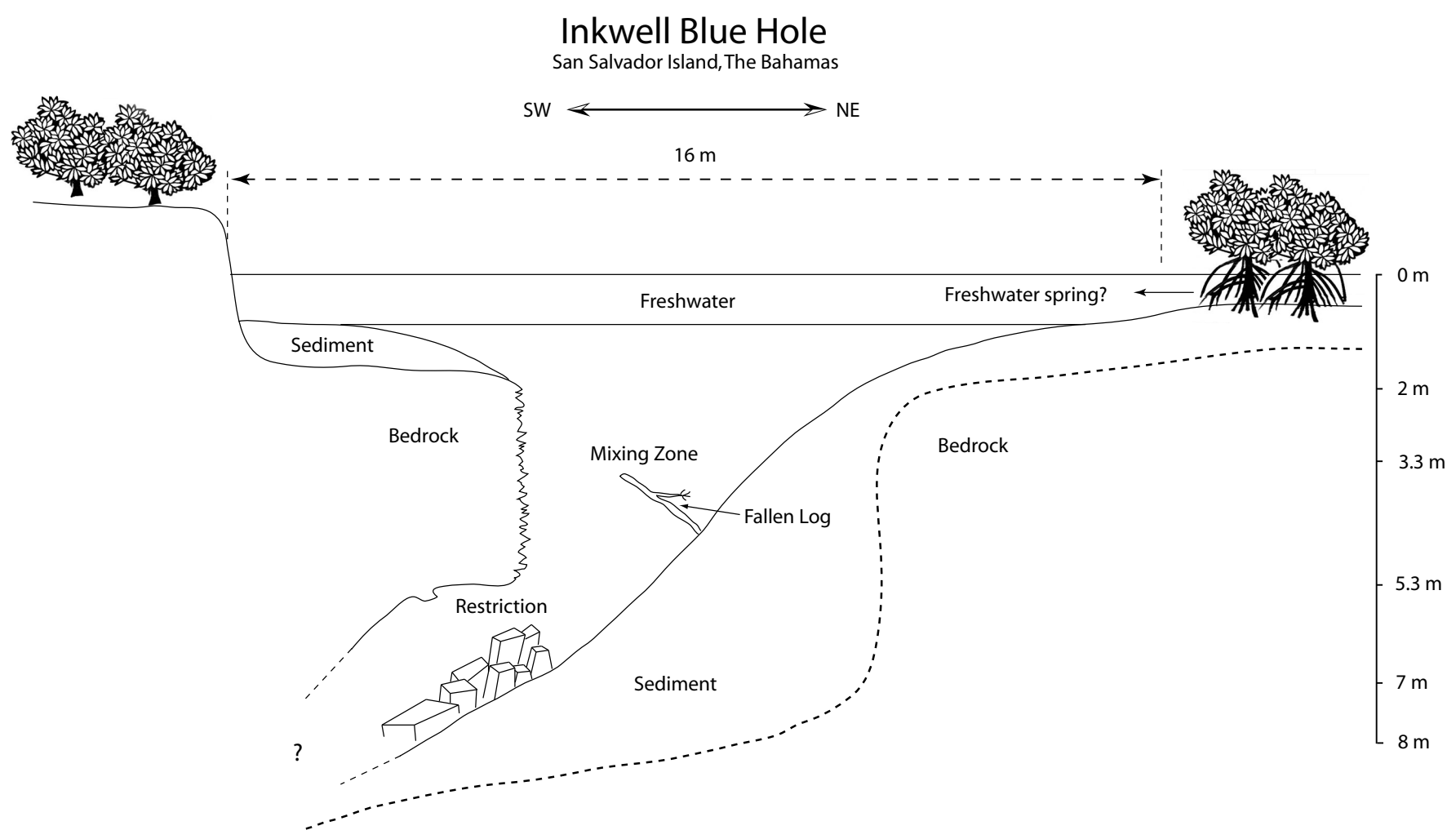

Fig. 2. Cross-section through the Inkwell Blue Hole (the blue holes sketches (Figs 2-4) were generated by G. Hunt, but the water stratification reflects the physicochemical data not his visual observations).

Inkwell Blue Hole (235'39.3” N, 74³2'58.0” W; Fig. 2) is $\sim 550 \mathrm{~m}$ from the coast, it has the smallest diameter $(\sim 16 \mathrm{~m})$ of the three blue holes but shares the same maximum depth $(\sim-8.5$ m) with Watling's Blue Hole. Vegetation surrounding this site is much denser than what was observed at the other two locations. Pumping equipment was present but not operating during the collection of the samples. Unknown quantities of water had been previously pumped out from near the surface of the blue hole judging from the depth to which the pipe was located.

The southwestern side contains a sheer, vertical exposure of an eolian dune from $\sim 2 \mathrm{~m}$ below water surface to the top of a cave entrance at $\sim-5.3 \mathrm{~m}$. The entrance is split by one breakdown pile, restricting diver access. The breakdown piles consist of medium to large blocks, mixed with sediment (sand, silt, algae, and terrestrial vegetation) and cobble infill. Observations could be made of the cave's interior that included two small, restricted tunnels. One of the tunnels appears to branch to the southeast toward Church Blue Hole, whereas the other tunnel appears to branch to the northwest toward Grotto Beach. The water in the column on the day of sampling (December 30, 2008) was nearly opaque from the surface to $\sim-3 \mathrm{~m}$ and clear through the remaining depths.

The diameter ( $\sim 32 \mathrm{~m})$ of Church Blue Hole (23⒌'36.1" N, $74^{\circ} 32^{\prime} 51.2^{\prime \prime} \mathrm{W}$ ) is twice the size of Inkwell but only half the size of Watling's and lies the furthest inland ( $750 \mathrm{~m})$. The vegetation surrounding the blue hole is similar but less dense than that of Inkwell with the exception of mangroves along the southern edge. This blue hole is shaped like a bowl to $\sim-1.5 \mathrm{~m}$ with a shaft in the center that continues to a depth of $\sim 4 \mathrm{~m}$ (Fig. 3). The pit contains a single small cave entrance on the northeast side at $-1.5 \mathrm{~m}$. The passage within seems (visibility in the water column was rather poor) to extend to the northwest toward Inkwell Blue Hole. The vertical conduit may continue downward but could not be determined since it was completely filled with sediment.

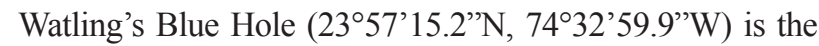
largest of the three sites with a diameter of $\sim 63 \mathrm{~m}$ and a depth of $\sim 8.5 \mathrm{~m}$ (Fig. 4). This site is the closest to the ocean, lying $\sim 500$ $\mathrm{m}$ from the southern shore of the island. An artificial rock wall ranging between $0.6 \mathrm{~m}$ and $0.9 \mathrm{~m}$ in height surrounds the blue hole. Residents built the wall in the 1800s as a holding pen for sea turtles (Carew and Mylroie, 1994). Vegetation at this site is sparse and is restricted from reaching the shore by the enclosure.

Northwest of the center point of the blue hole, at a depth of $\sim 7.3 \mathrm{~m}$, lies a 1 to $2 \mathrm{~cm}$ layer of duricrust. At $\sim-7.5 \mathrm{~m}$ we identified a cave entrance; the passage appears to continue in a northwestern direction. Due to extremely low visibility conditions (December 29, 2008), cave exploration stopped after only $10 \mathrm{~m}$. Sediments at the bottom of the blue hole slope steadily in a southwestern direction toward the cave entrance and are composed of cobbles covered with sand, silt, and an organicrich material (Fig. 4).

\section{SAMPLING AND ANALYTICAL METHODS}

In December 2008, divers collected water samples in $125 \mathrm{ml}$ high-density polyethtlene Nalgene bottles at varying depths. Water collection originated at the surface $(0 \mathrm{~m})$ and continued at $1 \mathrm{~m}$ depth intervals until reaching the bottom along a vertical transect centered over the deepest point at each location. The physical parameters were measured insitu using a HANNA HI 98280 portable multi-parameter data logger. GPS coordinates and values for $\mathrm{pH}$, temperature (T), electric conductivity (EC), salinity, and total dissolved solids (TDS) were collected at this time. Since temperature could not be collected at the point of sample collection, temperature and TDS data was collected only at the surface. Calibration of the data logger was conducted prior to sampling using HI9828-25 calibration solution in accordance with the manual directions. 


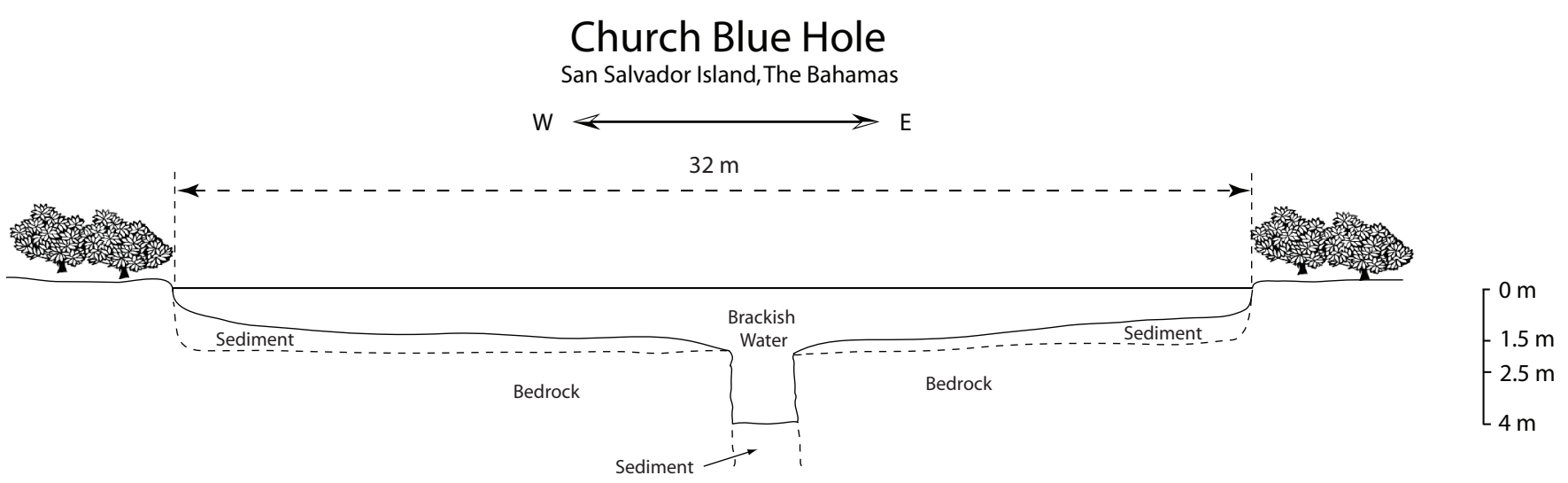

Fig. 3. Vertical profile through the Church Blue Hole.

To reduce cross contamination, the probes were rinsed with deionized water and wiped between the measurements.

Chemical parameters were measured in the laboratory using a Hach DR2700 Portable Spectrophotometer. The samples were processed according to the protocol required by each method as described on Hach's website. Analysis was completed within a few hours up to three days after collection. The spectrophotometer was used to analyze total hardness, $\mathrm{SO}_{4}{ }^{2-}, \mathrm{K}^{+}$, and $\mathrm{Cl}^{-}$. A Hach digital titration test kit (model AL-DT) was used to measure alkalinity while in the field. The method uses phenolphthalein and bromocresol green-methyl red indicator to identify the titration endpoint.

\section{RESULTS AND DISCUSSION}

Samples collected from Inkwell, Church, and Watling's blue holes show very different parameter values and distributions throughout the respective water columns. The measured values of each water sample are listed in Table 1. At the time of sampling, divers reported observing water stratification in all three blue holes; however, their visual observations are not supported by the data set. One possible explanation is that the stratification they noticed in the water column was in fact a termocline similar to what Herrera-Silveira and Comín (2000) reported from cenotes in Yucatan Peninsula.

\section{Physical parameters}

The simplest way to identify different water types and mixing patterns within the blue holes is to observe the fluctuations of salinity, EC, and TDS. Variations of measured parameters are known to increase in bodies of waters with an open conduit system (towards the sea/ocean) and are influenced by their location within the carbonate islands (Troester and White, 1986). Salinity variations can occur due to the mixing of different water types (Hem, 1989). At all locations we investigated the salinity values were in the brackish range. However, the TDS values recorded at the surface $(992 \mathrm{mg} / \mathrm{L})$ of Inkwell fall within the freshwater range of $<1000 \mathrm{mg} / \mathrm{L}$ (Table 1) (Hem, 1989).

In terrestrial environments (less than $1 \mathrm{~km}$ of the shoreline), measurements of salinity can indicate the lack of a fresh water layer because of the increased rate of mixing, and can resemble a density-stratified anchialine rather than a halocline. Blue holes with direct conduit connection to the ocean often have a visibly sharp interface accompanied by turbulent sheer at the density interface (Beddows et al., 2007). Roadman (1974) conducted a study in the Sandy Point area (likely at Inkwell), which reports salinity values that display a sharp density-stratification. However, the interface occurred $\sim 1.5 \mathrm{~m}$ lower than in our 2008 measurements (Fig. 5A).

Previous work conducted by Martin et al. (2012) investigated tidal fluctuations tracking the systematic changes of EC and $\mathrm{pH}$ values at Inkwell, determining that the blue hole exchanges a small amount of water with the surrounding rock matrix know as tidal pumping. Tidal pumping produces strong flows driven by the differences of head between the ocean, conduits, and matrix porosity. When the water flows toward the ocean the head in the matrix is higher resulting in flow from the matrix into the blue hole. Similarly, an incoming tide would allow for rapid water rise into the blue

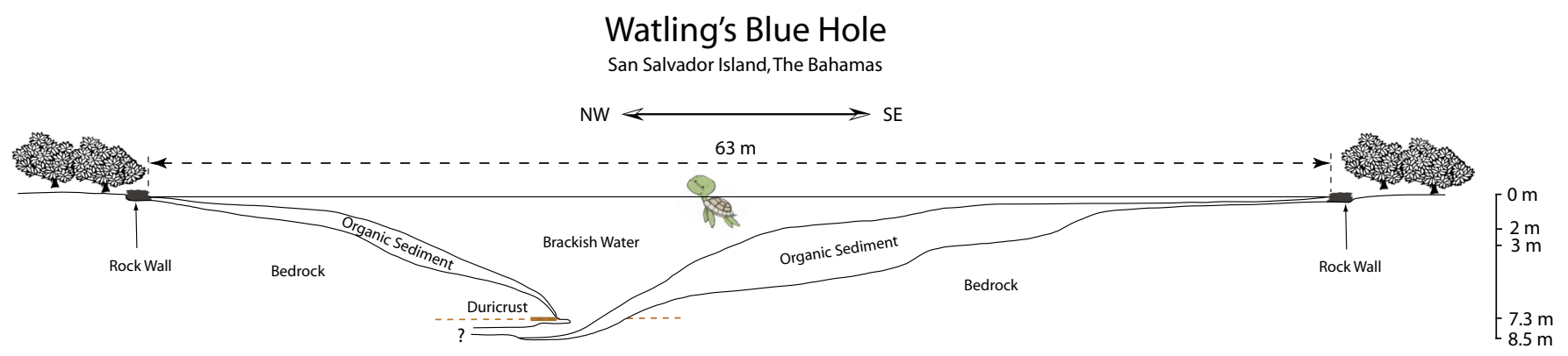

Fig. 4. Watling's Blue Hole cross-section. 
Table 1. Measured parameters of water samples in the three blue holes (values with standard deviation are based on three independent readings).

\begin{tabular}{|c|c|c|c|c|c|c|c|c|c|c|c|c|c|c|}
\hline Depth & $T$ & pH & TDS & Salinity & EC & Alk & \multicolumn{2}{|c|}{$\mathrm{Cl}^{-}$} & \multicolumn{2}{|c|}{$\mathbf{K}^{+}$} & \multicolumn{2}{|c|}{$\mathrm{SO}_{4}^{2-}$} & \multicolumn{2}{|c|}{ TH } \\
\hline (m) & $\left({ }^{\circ} \mathrm{C}\right)$ & & $(\mathrm{mg} / \mathrm{L})$ & (\%) & $(\mathrm{mS} / \mathrm{cm})$ & $(\mathrm{mg} / \mathrm{L})$ & $(\mathrm{mg} / \mathrm{L})$ & \pm & $(\mathrm{mg} / \mathrm{L})$ & \pm & $(\mathrm{mg} / \mathrm{L})$ & \pm & $(\mathrm{mg} / \mathrm{L})$ & \pm \\
\hline \multicolumn{15}{|c|}{ Inkwell } \\
\hline 0 & 22.54 & 7.68 & 992 & 1.01 & 1.98 & 132 & 300 & & 79.5 & 0.6 & 30 & 0 & 9 & \\
\hline 1 & & 7.70 & & 2.06 & 3.90 & 156 & 3600 & & 79.2 & 1.3 & 31 & 1 & 293 & \\
\hline 3 & & 7.43 & & 15.61 & 25.60 & 160 & 13800 & & 243.2 & 2.6 & 863 & 5 & 14 & \\
\hline 4 & & 7.53 & & 19.17 & 30.87 & 156 & 23800 & & 242.0 & 1.9 & 1006 & 3 & 12 & \\
\hline 5 & & 7.20 & & 21.59 & 34.38 & 158 & 9591 & $\begin{array}{l}33.93 \\
\end{array}$ & 315.1 & 1.7 & 1759 & 4 & 12 & \\
\hline 6 & & 7.46 & & 21.81 & 34.71 & 158 & 8415 & 33.45 & 317.9 & 0.6 & 1701 & 4 & 113 & \\
\hline 7 & & 7.38 & & 21.54 & 34.32 & 140 & 9112 & 52.79 & 310.9 & 2.8 & 1310 & 4 & $\mathrm{~N} / \mathrm{A}$ & \\
\hline 0 & 26.83 & 8.07 & 15120 & 18.74 & 30.19 & N/A & 10250 & 40.70 & 284.5 & 0.7 & 1258 & 3 & 8 & 0.6 \\
\hline 1 & & 8.18 & & 18.89 & 30.42 & 152 & 9840 & 62.02 & 254.0 & 1.5 & 1977 & 1 & 1 & 0.6 \\
\hline 2 & & 8.02 & & 18.98 & 30.65 & 162 & 8611 & 31.92 & 257.7 & 1.4 & 1069 & 3 & 4 & 0.6 \\
\hline 3 & & 7.48 & & 20.91 & 32.94 & 152 & 9123 & 31.65 & 296.4 & 1.0 & 1766 & 1 & 9 & 0.6 \\
\hline 4 & & 7.43 & & 20.91 & 33.51 & 148 & 8475 & 22.62 & 291.1 & 0.9 & 1750 & 4 & 9 & 0.0 \\
\hline 5 & & 7.42 & & 20.69 & 33.06 & 140 & 9737 & 60.78 & 308.7 & 0.8 & 1540 & 1 & 89 & 2.7 \\
\hline 6 & & 7.44 & & 21.74 & 34.58 & 152 & 9340 & 58.72 & 287.7 & 2.3 & 1779 & 1 & 11 & 0.0 \\
\hline 7 & & 7.66 & & 21.54 & 34.30 & 148 & 9517 & 19.90 & 320.0 & 0.9 & 1703 & 2 & 8 & 0.6 \\
\hline \multicolumn{15}{|c|}{ Church } \\
\hline 0 & 23.57 & 7.62 & 17100 & 21.47 & 34.20 & 112 & 24300 & & 199.5 & 1.6 & 2634 & 2 & 9 & 0.0 \\
\hline 1 & & 7.58 & & 17.78 & 28.10 & 140 & 19600 & & 246.4 & 1.1 & 4009 & 2 & 14 & 0.6 \\
\hline 3 & & 7.48 & & 18.73 & 30.22 & 144 & 7800 & & 259.5 & 2.5 & 2953 & 2 & 8 & 1.0 \\
\hline 4 & & 7.5 & & 18.74 & 32.23 & 138 & 8900 & & 264.6 & 2.4 & 3077 & 1 & 9 & 1.0 \\
\hline
\end{tabular}

T: temperature; TDS: total dissolved solids; EC: electric conductivity; Alk: alkalinity; TH: total hardness

hole from the conduits providing flow back into the matrix as proposed by Martin et al. (2012) in their Fig. 8. Fresh water that percolated into the rock matrix during the wet season could still be present in the pore spaces. The flux of the pore water from the rock matrix into the blue hole could explain the fresh water TDS values near the surface on the day of sampling. Additional TDS values would need to be collected to better evaluate the presence of freshwater. Result differences observed between the 1974 and current study could come from particular environmental settings (tidal cycles and/or freshwater input at the time of sampling, amount of precipitation/evaporation prior to collecting the data, etc.).

A conduit connection with the ocean is assumed to exist at Watling's based on the limited fluctuation of salinity (18.74 $21.54 \%$ o) and EC $(30.19-34.30 \mathrm{mS} / \mathrm{cm})$ that steadily increase with depth. In addition, we witnessed a clear water-level lowering during the time of sampling that coincided with the onset of low tide. Vermette and Hudson's (2001) study of Watling's concluded that there was no identifiable fresh/brackish water lens, halocline, or stratification with depth that would suggest mixing of the water column. Therefore, the absence of these features would be consistent with a direct conduit connection to the ocean (Davis and Johnson, 1989; Vermette and Hudson, 2001).

The samples collected by Vermette and Hudson in 2001 had salinity values ranging from $37.76 \%$ at the surface to $\sim 40.00 \%$ o at $\sim-7 \mathrm{~m}$. In contrast, the samples collected in 2008 had brackish salinity values ranging from $18.74 \%$ at the surface to $21.54 \%$ o at $-7 \mathrm{~m}$ (Fig. 5A). The differences in salinity values could be a result of different sampling times during the tidal cycle or/ and seasonality coupled with the effects of evaporation. The 2001 samples were collected in the last month of the dry season (April) whereas the 2008 samples were collected early in the dry season (December). Another possible reason for seeing these differences between the two data sets resides in the method used to recover the water samples (diving vs. Van Doren bottle).

Church Blue Hole is the least of the three blue holes with respect to the degree of influence by tidal fluctuations. The location of the blue hole and the lack of significant changes of all measurements, excluding $\mathrm{Cl}^{-}$, within the water column may argue for very narrow conduits or more likely matrix flow (Fig. 5). Salinity values are higher at the surface $(21.47 \%$ ) compared to the lower depths where the average is
$18.49 \pm 0.82 \%$ (Fig. 5A). The high sulfate values throughout the column, which range between $2634-4009 \mathrm{mg} / \mathrm{L}$ are characteristic of seawater $(>2700 \mathrm{mg} / \mathrm{L})$ and could be the result of seawater seepage into the blue hole (Table 1). The elevated salinity at the surface and $-1 \mathrm{~m}$ horizon could be a result of evaporation coupled with a limited circulation within the water column and/or from/to pore matrix.

Conditions such as poor visibility, circular shape, parallel sides, and flat bottom suggest that Church Blue Hole may be more accurately described as a black hole. Black holes appear to have no direct link to the ocean except through the rock matrix and develop from the surface down. Schwabe and Herbert (2004) explain the morphology of the black hole as a result of fresh water interaction with sulfide-rich seawater seepage that creates a zonation beneficial for phototrophic bacterial growth responsible for the black appearance of the water. The bowl shape is created by a more rapid lateral widening, rather than vertical deepening; this process might be caused by the stabilization of the physiochemical parameters in the lower part of the water column (Fig. 3) (Schwabe and Herbert, 2004).

\section{Chemical parameters}

The distribution of the chemical values is different at each location in response to the type of waters that mix (Fig. 5BD). No relationships can be established between alkalinity, $\mathrm{Cl}^{-}, \mathrm{K}^{+}, \mathrm{SO}_{4}{ }^{2-}$, and total hardness in the water column of the blue holes assumed to have conduit connection (Inkwell and Watling's) to the ocean. Yet at the non-conduit location (Church) the values for alkalinity, $\mathrm{K}^{+}, \mathrm{SO}_{4}{ }^{2-}$, and total hardness are inversely related to $\mathrm{Cl}^{-}$, until $-3 \mathrm{~m}$ where $\mathrm{Cl}^{-}$significantly increases from 1800 to $7800 \mathrm{mg} / \mathrm{L}$ (Fig. 5D).

Chloride does not readily enter into oxidation/reduction reactions unless the levels of $\mathrm{Cl}^{-}$are excessive. However, the difference between the two values can be useful for assessing the aggressiveness of the mixing process (Hem, 1989). The bottom of the mixing zone is easily found for Inkwell and Church by identifying the point at which the fluctuation between two depths is the least (Fig. 5D). Both can be identified as receiving seawater due to the elevated chloride values ( $>$ $19000 \mathrm{mg} / \mathrm{L}$ ), as suggested by Whitaker and Smart (2007) in their study of northern Bahamas blue holes (Table 1). 

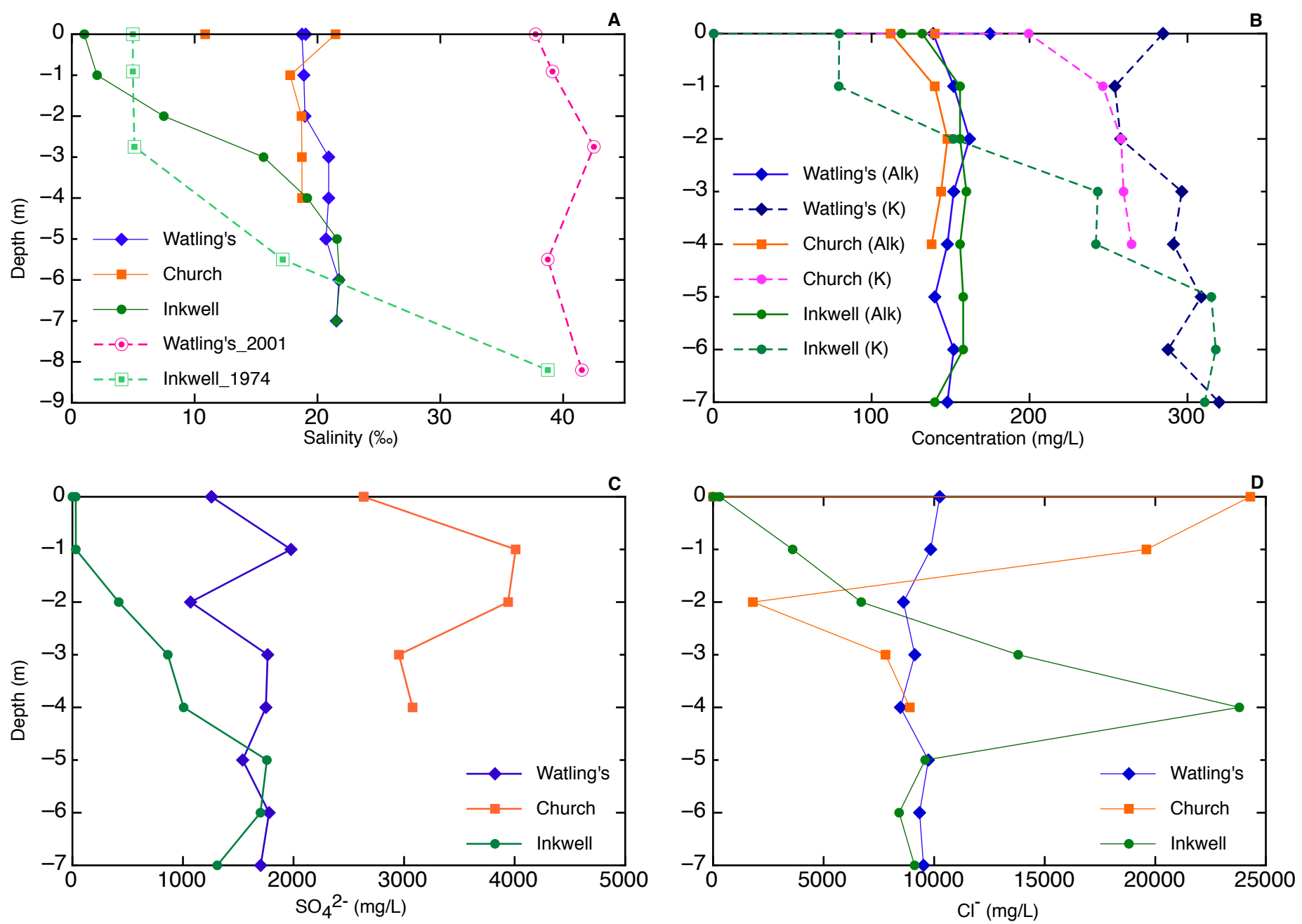

Fig. 5. Profiles in the three blues showing concentration versus depth fluctuations of a) salinity, b) alkalinity and potassium, c) sulfates, and d) chloride. Salinity plots for Watling's and Inkwell labeled Watling's_2001 and Inkwell_1974, respectively are based on data from Vermette and Hudson (2001) and Roadman (1974).

Sulfate can be useful in the identification of seawater and boundary limits of the mixing zones in blue holes. Sulfate derived from seawater will increase sharply in the lower half of the mixing zone as seen in Inkwell at $-5 \mathrm{~m}$ and Church at $-1 \mathrm{~m}$ (Fig. $5 \mathrm{C}$ ). The reduction of $\mathrm{SO}_{4}^{2-}$ by bacterial activity occurs in the lower portion of the mixing zone and is overlain by reoxidized $\mathrm{SO}_{4}^{2-}$ in the upper portion of the mixing zone (Bottrell et al., 1991). Lower $\mathrm{SO}_{4}^{2-}$ values overlain by increased values are seen at $-7 \mathrm{~m}$ in Inkwell; -1 , -3 , and $-6 \mathrm{~m}$ in Watling's and at $-1 \mathrm{~m}$ in Church (Fig. 5C). All of the $\mathrm{SO}_{4}{ }^{2-}$ values within Church are indicative of seawater (>2700 mg/L; Table 1). The patterns of the fluctuations within Inkwell and Watling's identify both locations as having direct contact with the ocean but yet are influenced in different ways. Non-conduit flows can resemble some of the patterns seen in conduit locations but are usually further inland and are better identified by chemical parameters.

\section{CONCLUSION}

The use of physiochemical data to identify geochemical changes within blue holes has the potential to provide a more complete picture of water-rock interactions. By combining the physical and chemical parameters of each blue hole we can identify possible hydrological patterns and specific geochemical properties. Inkwell appears to connect to the ocean by conduits as suggested by various parameters that are influenced by tidal pumping. The bottom of the mixing zone in this blue hole is located below $-4 \mathrm{~m}$ in depth. The gradient seen in the $\mathrm{Cl}^{-}$values at Inkwell suggest significant mixing in the water column beginning at a depth of $\sim 1 \mathrm{~m}$; this process could mask the presence of a thicker fresh water lens. Elevated $\mathrm{K}^{+}$values $>300 \mathrm{mg} / \mathrm{L}(390 \mathrm{mg} / \mathrm{L}$ is seawater) and $\mathrm{Cl}^{-}$values indicative of seawater at $\sim-4 \mathrm{~m}$ and below may indicate that seawater may be entering the blue hole below $-4 \mathrm{~m}$ (Table 1). Inkwell is the only location that possible dissolution could be determined, dissolution is likely occurring between the surface and $-1 \mathrm{~m}$. We infer this process from the elevated value of the total hardness $(293 \mathrm{mg} / \mathrm{L})$ that exceeds the alkalinity value $(156 \mathrm{mg} / \mathrm{L})$, and the low EC values $(<\sim 4.4 \mathrm{mS} / \mathrm{cm})$ that are dependent on carbonate dissolution (Table 1) (Beddows et al., 2007). Another blue hole connected by conduits to the ocean is Watling's. However, the lack of significant variation in the measured parameter values indicates limited mixing is taking place. Church Blue Hole is a non-conduit location that may be influenced by evaporative processes accounting for the elevated levels of salinity and $\mathrm{Cl}^{-}$at the surface. We speculate that the anticorrelation between $\mathrm{SO}_{4}{ }^{2-}$ and $\mathrm{Cl}^{-}$is the result of some mixing processes in the water column and/or the possible presence of bacteria (Fig. 5C, D).

Futures studies should include temperatures throughout the water column, combined with values for TDS, dissolved oxygen, 
and oxidation-reduction potential to enhance the information already collected. Isotopic information derived from measuring $\delta^{34} \mathrm{~S}$ in water and bedrock sulfates would be useful in assessing the role of bacteria in various chemical reactions occurring within the water column or at the water/rock interface. Subsequent studies of these blue holes should be conducted preferably during both seasons to increase the probability of recognizing any physiochemical differences that may occur over longer periods of time. In turn, these may shed light on various processes that take place at the water/rock interface and in the water column, thus allowing for a better understanding of the karst hydrology of the island.

Acknowledgements. We thank the Gerace Research Centre and Dr. Tom Rothfus on San Salvador Island, Bahamas for logistical support of our research, and the Bahamian Government for granting permission to do research on the island. The authors would like to thank Drs. B.P. Onac, J. Carew, R.L. Davis, and J. Mylroie for discussions and suggestions. Students, L. Brewer, J. Cunio, C. Griffith, G. Hunt, J. Fredericks, J. Nattrass, T. Paolillo, G. Ponta, W. Wakefield, and J. Zydek are acknowledged for helping in the collection of water samples and conducting chemical analyses. This project was partially supported by the University of South Florida internal grant to B.P. Onac.

\section{REFERENCES}

Alcocer, J., Lugo, A., Marin, L.E. \& Escobar, E. 1998, Hydrochemistry of waters from five cenotes and evaluation of their suitability for drinking-water supplies, northeastern Yucatan, Mexico. Hydrology Journal, 6: 293-301.

Back, W., Hanshaw, B.B., Herman, J.S. \& Van Driel, J.N. 1986, Differential dissolution of a Pleistocene reef in the ground-water mixing zone coastal Yucatan, Mexico. Geology, 14: 137-140. http://dx.doi.org/10.1130/0091-7613(1986)14<137:DDOAPR >2.0.CO;2

Beddows, P.A., Smart, P.L., Whitaker, F. \& Smith, S.L. 2007. Decoupled-fresh-saline groundwater circulation of a coastal carbonate aquifer: Spatial patterns of temperature and specific electrical conductivity. Journal of Hydrology, 346: 18-32. http://dx.doi.org/10.1016/j.jhydrol.2007.08.013

Bottrell, S.H., Smart, P.L., Whitaker, F. \& Raiswell, R. 1991, Geochemistry and isotope systematics of sulphur in the mixing zone of Bahamian blue holes. Applied Geochemistry, 6: 97-103. http://dx.doi.org/10.1016/0883-2927(91)90066-X

Burkeen, B., Mylroie, J.E. 1992, Bahamian blue holes: description and definition. National Speleological Society Bulletin, 54: 92-93.

Carew, J.L., Mylroie, J.E., 1994, Geology and Karst of San Salvador Island, Bahamas: A Field Trip Guidebook, Bahamian Field Station, San Salvador, Bahamas.

Carew, J.L., Mylroie, J.E., 1995, Quaternary tectonic stability of the Bahamian Archipelago; evidence from fossil coral reefs and flank margin caves. Quaternary Science Reviews, 14: 145-153. http://dx.doi.org/10.1016/0277-3791(94)00108-N

Davis, R.L., Johnson C.R. Jr. 1989, Karst hydrology of San Salvador. In $4^{\text {th }}$ Symposium on the Geology of the Bahamas: Port Charlotte, Florida (Mylorie, J.E., Ed.), Bahamian Field Station.

Farr, R.F., Palmer, R. 1984, The blue holes: description and structure. Cave Science, 11: 9-22.

Hem, J.D. 1989, Study and interpretation of the chemical characteristics of natural waters. U.S. Geological Survey Water-Supply Paper 2254, 263 p.

Herrear-Silveira, J.A., Comín, F.A. 2000, An Introductory account of the types of aquatic ecosystems of Yucatan Peninsula (SE Mexico). In Ecovision World Monographs Series. Aquatic Ecosystems of Mexico: Status \& Scope (Munawar, M., Lawrence, S.G., Munawar, I.F. \& Malley, D.F., Eds.), Backhuys Pub. Leiden, 213-227.
Martin, J.B., Gulley, J. \& Spellman, P. 2012, Tidal pumping of water between Bahamian blue holes, aquifers and the ocean. Journal of Hydrology, 416-417: 28-38. http://dx.doi.org/10.1016/j.jhydrol.2011.11.033

McGee, D., Wynn, J.G., Onac, B.P., Harries, P.J. \& Rothfus, E.A. 2010, Tracing groundwater geochemistry using $\delta^{13} \mathrm{C}$ on San Salvador Island (southeastern Bahamas): implications for carbonate island hydrogeology and dissolution. Carbonates and Evaporites, 25: 91-105. http://dx.doi.org/10.1007/s13146-010-0013-6

Moore, P.J., Martin, J.B. 2006, Water chemistry on San Salvador Island, Bahamas. In The $13^{\text {th }}$ Symposium on the geology of the Bahamas and other carbonate Regions, 1-10.

Mylroie, J.E. 2004, Blue holes of the Bahamas. In Encyclopedia of caves and karst science (Gunn, J., Ed.), Fitzroy Dearborn, London, 155-156.

Mylroie, J.E. 2008, Late Quaternary sea-level position: Evidence from Bahamian carbonate deposition and dissolution cycles. Quaternary International, 183: 61-75. http://dx.doi.org/10.1016/j.quaint.2007.06.030

Mylroie, J.E., Carew, J.L. 1990, The flank margin model for dissolution cave development in carbonate platforms. Earth Surface Processes and Landforms, 15: 413-424. http://dx.doi.org/10.1002/esp.3290150505

Mylroie, J.E., Carew, J.L. 1995a, Geology and karst geomorphology of San Salvador Island, Bahamas. Carbonates and Evaporites, 10: 193-206. http://dx.doi.org/10.1007/BF03175404

Mylroie, J.E., Carew, J.L. 1995b, Karst development on carbonate islands. In Unconformities in carbonate strata their recognition and the significance of associated porosity (Budd, D.A., Saller, A.H. \& Harris, P.M., Eds.), American Association of Petroleum Geologists Memoir, 63: 55-76.

Mylroie, J.E., Mylroie, J. 2009, Caves of the Bahamas. Rapid cave formation in very young limestones. In Proceedings of the $15^{\text {th }}$ International Congress of Speleology, Kerrville, TX. Guidebook for excursion No. 82, 76 p.

Mylroie, J.E., Carew, J.L. \& Moore, A.I. 1995, Blue holes: definition and genesis. Carbonates and Evaporites, 10 (2): 225-233. http://dx.doi.org/10.1007/BF03175407

Palmer, R.J. 1985, The blue holes of the Bahamas. Jonathan Cape, London, 184 p.

Robinson, M.C., Davis, R.L. 1999, Map of San Salvador, San Salvador GIS Database. University of New Haven \& Bahamian Field Station. http://www.newhaven.edu/1404

Rodman, K. 1974, Soil and Water Conductivity, Environmental Chemistry Notes. Bahamian Field Station, San Salvador Bahamas.

Schwabe, S., Herbert, R.A. 2004, Black Holes of the Bahamas: what they are and why they are black. Quaternary International, 121:3-11.

http://dx.doi.org/10.1016/j.quaint.2004.01.019

Schwabe, S.J., Palmer, R., Herbert, R.A. \& Carew, J.L. 2008, A hypothesis for biogenic cave formation: A study conducted in the Bahamas. In Proceedings of the $13^{\text {th }}$ Symposium on the Geology of the Bahamas and other Carbonate Regions. 141-152.

Sealey, N.E. 1994, Bahamian landscapes. An introduction to the geology and physical geography of The Bahamas $\left(3^{\mathrm{rd}}\right.$ ed.), Macmillan, Oxford, $174 \mathrm{p}$.

Shaw, T. 1993, The history of cave studies in Trinidad, America, the Bahamas, and some other Caribbean Islands. Acta Carsologica, 22: 11-76.

Troester, J., White, W.B. 1986, Geochemical investigations of three tropical karst drainage basins in Puerto Rico. Ground Water, 24 (4): 475-482.

http://dx.doi.org/10.1111/j.1745-6584.1986.tb01026.x

Vacher, H.L., Mylroie, J.E. 2002, Eogenetic karst from the perspective of an equivalent porous medium. Carbonates and Evaporites, 17 (2): 182-196. http://dx.doi.org/10.1007/BF03176484 
Vacher, H.L., Quinn, T.M. 1997, Geology and hydrogeology of carbonate islands. Elsevier, Amsterdam, 207 p.

van Hengstum, P.J., Scott, D.B. 2011, Ecology of foraminifera and habitat variability in an underwater cave: distinguishing anchialine versus submarine cave environments. Journal of Foraminiferal Research, 41: 201-229. http://dx.doi.org/10.2113/gsjfr.41.3.201
Vermette, S., Hudson, R. 2001, Hydrology of Watling's Blue Hole: San Salvador, Bahamas. Middle States Geographer, 34: 55-62.

Whitaker, F.F., Smart, P.L. 2007, Geochemistry of meteoric diagenesis in carbonate islands of the northern Bahamas: 1. Evidence from field studies. Hydrological Processes, 21: 949-966. http://dx.doi.org/10.1002/hyp.6532 